\title{
Rosiglitazone improves the natriuretic response to atrial natriuretic peptide in rats with experimental congestive heart failure: possible involvement of a post-guanylate cyclase mechanism
}

\author{
Ilia Goltsman*, Elena Ovcharenko, Aaron Hoffman, Giora Feuerstein, Zaid Abassi, Joseph Winaver
}

From 5th International Conference on cGMP: Generators, Effectors and Therapeutic Implications Halle, Germany. 24-26 June 2011

\section{Background}

Congestive heart failure (CHF) in patients and experimental animals is characterized by renal retention of salt and water and a blunted natriuretic/diuretic response to atrial natriuretic peptide (ANP). Recently, we reported that chronic treatment with the PPAR $\gamma$ agonist rosiglitazone (RGZ) improved the natriuretic and diuretic responses to extracellular fluid volume expansion in rats with aorto-caval fistula, an experimental model of volume-overload CHF [1]. In the present study we explored whether RGZ improves also the natriuretic/diuretic response to ANP in rats with experimental CHF. In addition, we evaluated the effects of the drug on ANP-mediated cGMP signalling in the kidney.

\section{Methods}

CHF was induced in male Sprague-Dawley rats by surgical formation of a fistula between the aorta and inferior vena cava $(1.2 \mathrm{~mm}$ O.D.). The natriuretic/diuretic responses and urinary cGMP (UcGMP) excretion in response to rat ANP (15 and $50 \mu \mathrm{g} / \mathrm{kg} / \mathrm{hr}$, low and high doses, respectively) were assessed by clearance methodology in CHF rats following 2 weeks of RGZ (30 mg/ $\mathrm{kg} /$ day, p.o.) or vehicle (Veh) treatment, and in shamoperated controls $(\mathrm{N}=6-10)$. The capacity of isolated glomeruli and collecting ducts to generate cGMP invitro in response to ANP $\left(10^{-11}-10^{-6} \mathrm{M}\right.$, in the presence

\footnotetext{
* Correspondence: goltsman@tx.technion.ac.il Department of Physiology and Biophysics, Faculty of Medicine, Technion-IIT, Haifa, Israel
}

of 1.0 mM IBMX) was tested. Urinary and tissue cGMP levels were measured using ELISA. Moreover, to screen for relevant gene expression targets of RGZ (renal cortex and medulla samples, $\mathrm{N}=3$ in each group), quantitative real-time PCR was performed using Taqman ${ }^{\circledR}$ array plates testing 32 selected genes related to ANP/cGMP signalling and controls.

\section{Results}

CHF rats exhibited a markedly blunted natriuretic response to ANP administration. RGZ treatment significantly improved the natriuretic/diuretic action of ANP in CHF rats compared with Veh treatment, as represented by urinary sodium excretion rate (Control+Veh: $1.3 \pm 0.3$ to $9.2 \pm 2 \mu \mathrm{Eq} / \mathrm{min}, \mathrm{CHF}+\mathrm{Veh}: 0.3 \pm 0.16$ to 2.3 $\pm 0.7^{*} \mu \mathrm{Eq} / \mathrm{min}, \mathrm{CHF}+\mathrm{RGZ}: 2.3 \pm 0.7$ to $9.5 \pm 1.9^{\dagger} \mu \mathrm{Eq} / \mathrm{min}$, baseline to low dose ANP values, " $\mathrm{p}<0.05$ vs. Control + Veh, ${ }^{\dagger} \mathrm{p}<0.05$ vs. CHF+Veh). However, UcGMP excretion was similarly increased in response to ANP and did not differ between CHF rats treated with RGZ or Veh (Control+Veh: $14 \pm 3$ to $129 \pm 26 \mathrm{pmol} / \mathrm{ml}$, CHF+Veh: 65 \pm 10 to $127 \pm 15 \mathrm{pmol} / \mathrm{ml}, \mathrm{CHF}+\mathrm{RGZ}: 47 \pm 10$ to $143 \pm 22$ $\mathrm{pmol} / \mathrm{ml}$, GFR-normalized values, $\mathrm{p}=\mathrm{NS}$ ). Also, $\mathrm{RGZ}$ treatment did not alter the capacity to generate cGMP in response to ANP in isolated renal tissues. Finally, preliminary gene expression study revealed several genes related to renal ANP/cGMP signalling and $\mathrm{Na}^{+}$transport regulation that were significantly altered by RGZ treatment in rats with CHF (see Figure 1).

\section{Biomed Central}




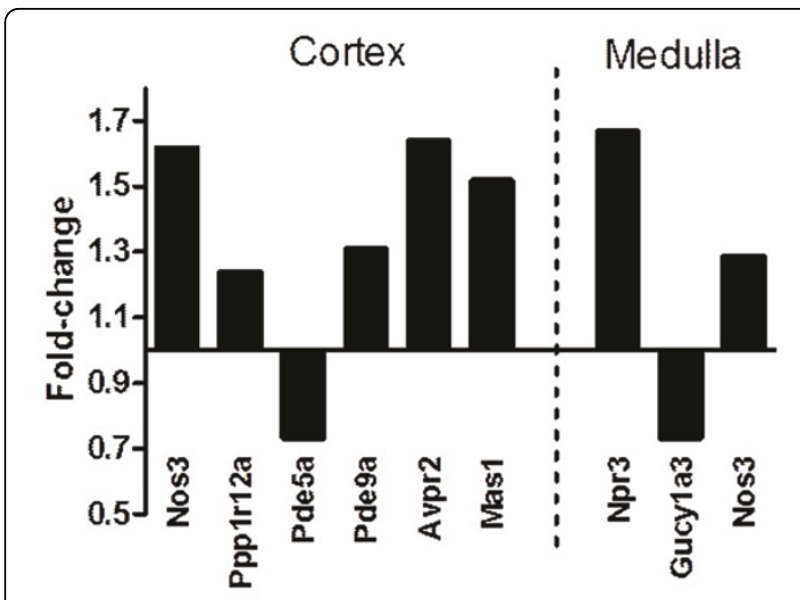

Figure 1 Renal RGZ-regulated genes related to ANP signalling and $\mathrm{Na}^{+}$transport in rats with CHF. Fold-change represent comparison of $\mathrm{CHF}+\mathrm{RGZ}$ vs. CHF+Veh ( $\mathrm{N}=3$ each). P-values for all comparisons are lower than 0.07. Averaged values for Gapdh, Ppia and Gusb were used as normalizers and the sham-control group served as the calibrator. Nos3, endothelial NO synthase; Ppp1r12a, myosin phosphatase-targeting subunit 1; Pde5/9a, cGMP-specific phosphodiesterases; Avpr2, Arginine vasopressin receptor 2; Mas1, Ang(1-7) receptor Mas; Npr3, Natriuretic peptide receptor C; Gucy1a3, soluble guanylate cyclase $\alpha 1$-subunit.

\section{Conclusion}

In rats with experimental CHF, chronic RGZ treatment enhances renal ANP-induced natriuresis, probably at a step beyond cGMP generation. Furthermore, the data reveal several gene expression targets, including members of the phosphodiesterase family, eNOS and Mas receptor, that may be involved in the improvement in ANP-induced natriuresis.

Published: 1 August 2011

\section{Reference}

1. Goltsman I, Wang X, Lavallie ER, Diblasio-Smith EA, Ovcharenko E, Hoffman A, Abassi Z, Feuerstein GZ, Winaver J: Effects of chronic rosiglitazone treatment on renal handling of salt and water in rats with volume-overload congestive heart failure. Circ Heart Fail 2011, 4:345-354.

doi:10.1186/1471-2210-11-S1-P29

Cite this article as: Goltsman et al:: Rosiglitazone improves the natriuretic response to atrial natriuretic peptide in rats with experimental congestive heart failure: possible involvement of a postguanylate cyclase mechanism. BMC Pharmacology 2011 11(Suppl 1):P29.

\section{Submit your next manuscript to BioMed Central and take full advantage of:}

- Convenient online submission

- Thorough peer review

- No space constraints or color figure charges

- Immediate publication on acceptance

- Inclusion in PubMed, CAS, Scopus and Google Scholar

- Research which is freely available for redistribution

Submit your manuscript at www.biomedcentral.com/submit
C Biomed Central 